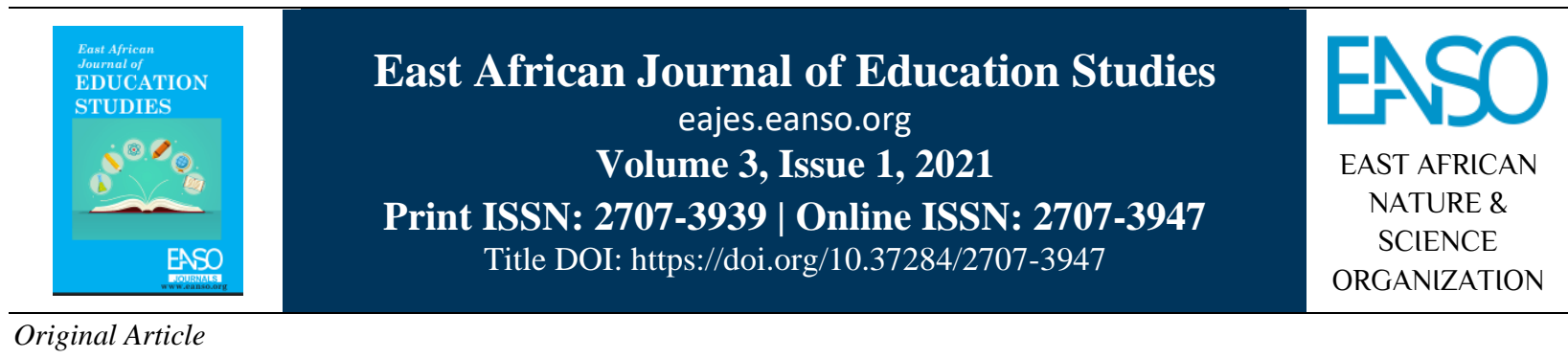

\title{
Innovative Instructional Strategies Used in Teaching of English Subject in Public Secondary Schools in Turkana Central Sub-County
}

\author{
Ignatius Ekitela Akolom ${ }^{* 1}$ Dr. Edwin Nyongesa Masibo, PhD \& Dr. Ben Nyongesa, PhD ${ }^{1}$ \\ 1* Kibabii University, P. O. Box 1699 - 50200, Bungoma, Kenya. \\ * ORCID: https://orcid.org/0000-0003-2716-2838; Correspondence Email: akolomignatius@ gmail.com.
}

Article DOI: https://doi.org/10.37284/eajes.3.1.363

\section{Date Published: ABSTRACT}

21 July 2021 The aim of this paper is to look at how teachers of English used various instructional strategies in teaching the subject in public secondary schools in

Keywords: Turkana Central Sub-County, Kenya. This paper is guided by Rogers's innovation-decision process theory. The study specifically examined the

Innovative, commonly used innovative instructional strategies in the teaching of English in

Instructional, public secondary schools and their effect on students' performance in English

Strategies, subjects in secondary schools in Turkana Central Sub-County. The study was

English anchored on mixed-method research methodology. The study target population involved all Heads of Department of Languages (10), Teachers of English (35)

Performance, and Form III students (486) from 10 public secondary schools in Turkana

Teaching Central Sub-County. A sample of 10 HODs, 35 teachers of English and 146 students was selected to represent the entire population. Data collection was through questionnaires and interview schedules. Data analysis was performed using descriptive and inferential statistics. Research results showed that the two most commonly used innovative teaching strategies were communicative language teaching and constructivist language teaching. It was found out that majorly many teachers resort to the conventional teacher centred approaches of teaching. The research recommends that KICD needs to align secondary school syllabus with innovative instructional approaches, teachers need to be trained regularly on innovative instructional strategies, and supportive infrastructure to be provided in schools to ensure innovative and technological approaches are used in English subject teaching and learning in secondary schools in Turkana Central Sub-County.

185 | This work is licensed under a Creative Commons Attribution 4.0 International License. 


\section{APA CITATION}

Akolom, I. E., Masibo, E. N. \& Nyongesa, B. (2021). Innovative Instructional Strategies Used in Teaching of English Subject in Public Secondary Schools in Turkana Central Sub-County. East African Journal of Education Studies, 3(1), 185-198. https://doi.org/10.37284/eajes.3.1.363.

\section{CHICAGO CITATION}

Akolom, Ignatius Ekitela, Edwin Nyongesa Masibo and Ben Nyongesa. 2021. "Innovative Instructional Strategies Used in Teaching of English Subject in Public Secondary Schools in Turkana Central Sub-County". East African Journal of Education Studies 3 (1), 185-198. https://doi.org/10.37284/eajes.3.1. 363.

\section{HARVARD CITATION}

Akolom, I. E., Masibo, E. N. and Nyongesa, B. (2021) "Innovative Instructional Strategies Used in Teaching of English Subject in Public Secondary Schools in Turkana Central Sub-County”, East African Journal of Education Studies, 3(1), pp. 185-198. doi: 10.37284/eajes.3.1. 363 .

\section{IEEE CITATION}

I. E. Akolom, E. N. Masibo, and B. Nyongesa, "Innovative Instructional Strategies Used in Teaching of English Subject in Public Secondary Schools in Turkana Central Sub-County”, EAJES, vol. 3, no. 1, pp. 185-198, Jul. 2021.

\section{MLA CITATION}

Akolom, Ignatius Ekitela, Edwin Nyongesa Masibo and Ben Nyongesa. "Innovative Instructional Strategies Used in Teaching of English Subject in Public Secondary Schools in Turkana Central Sub-County". East African Journal of Education Studies, Vol. 3, no. 1, Jul. 2021, pp. 185-198, doi:10.37284/eajes.3.1.363.

\section{INTRODUCTION}

The primary purpose of teaching at any level of education is to bring a fundamental change in the learner (Tebabal \& Khassay, 2011). Khan (2008) stated that education is a teaching and learning process. Learning depends upon the process of instruction. To facilitate the process of instruction in our classrooms, educators should apply appropriate teaching strategies that achieve specific objectives and level exit outcomes. These approaches can be categorised as conventional (traditional) or nonconventional (innovative) strategies. In the traditional strategies, most teaching practitioners widely applied teacher-centred strategies to impart knowledge to learners as opposed to student-centred strategies (Ganyaupfu, 2013). However, questions about the effectiveness of teaching strategies on student learning and performance in schools have consistently raised considerable interest in the thematic field of educational research (Hightower et al., 2011). Furthermore, research on teaching and learning constantly endeavour to examine the extent to which different teaching strategies enhance growth in student learning (Ganyaupfu, 2013).

This study investigated the influence of innovative instructional strategies on the performance of students in English subject in public secondary schools. The strategies comprise of integration of technology, role-play, brainstorming, cooperative learning, inquiry strategies among others. This research sought to establish various innovative instructional strategies in the classroom. Anburaj, Christopher and Ming (2014) indicated that innovative instructional strategies assist in bringing change in classroom instruction by making them better. For instance, they indicated that the innovative strategies help to enact stories, teach conversations, incorporate creative projects and assignments with the help of multimedia (audiovisual resources). Vitthal, Sharma and Ramachandran (2015) indicated that teachers' usage of brainstorming instructional approach provides students with a single stimulus that serves as a clue for a large number of responses. The approach provides a large volume of productive language practice on the part of the students relative to the contribution of the teacher and that it allows students to compose utterances at a convenient level for them (Al-Shammari, 2015).

Tran (2014) said that cooperative, collaborative and participative instructional strategies help learners to work together in groups of varying composition to achieve common objectives during an English lesson. For teachers of English to achieve success when using these approaches, students share ideas rather than working alone and assist one another in order to maximize mutual benefits (Dyson \& Casey, 2012). The inquiry-based learning demands that students are actively participating in their own 
learning (Khan et al., 2011). Inquiry based strategies allow for students to interact with their surroundings, ask questions, and draw conclusions by thinking critically and logically (Alameddine \& Ahwalb, 2016). Common innovative language strategies are the ones that integrate technology because ICT has become essential in schools. Technology in learning institutions has become essential and mobile with laptop computers, tablet devices, and smart phones now being part of the teaching and learning process (Ismail, 2018; Mothe, 2018). Advances in technology in Australia have influenced the way people create, share, use, and develop information in society, and that young people need to be highly skilled in their use of information and communication technology (ICT) (Eady \& Lockyer, 2013).

\section{Statement of the Problem}

It is obvious knowledge that teachers need to be practically equipped with innovative strategies in order to produce better results. Accordingly, many strategies and approaches have been identified and practiced and have led to better achievements (Endeshaw, 2015). Ganyaupfu (2013) maintains that in the 21st century, educators need to be cognizant with the fact that innovative instructional strategies should take into consideration the magnitude of the complexity of the concepts to be covered. To this end, there have been initiatives taken by different countries to address students' language performance in schools. However, the situation in Kenya is much different. Students' performance in English at the KCSE examinations has been consistently low and Turkana Central SubCounty in particular. English Paper two which tests comprehension, literary appreciation, and grammar has been singled out as the least performed. The poor syllabus coverage, inadequate teaching materials, students' attitude towards English, and poor teaching strategies maybe some of the contributing factors (Ongalo et al., 2013). It was, therefore, against this backdrop that the study investigated how innovative instructional strategies affected students' performance in English in public secondary schools in Turkana Central Sub-County, Turkana County, Kenya.

\section{THEORETICAL FRAMEWORK}

This paper is anchored on Rogers's (1995) innovation-decision process theory that is classified as one of the changes theories in the education sector but it applies in other disciplines as well. According to Rogers, the tenets of this theory are based on five phases; knowledge, persuasion, decision, implementation and confirmation. According to Sockman (2015), the first phase is divided into awareness knowledge and how-to knowledge in which a person performs an inactive role in looking at changes. The second stage of persuasion is commonly effective, in that the individual is subjected to perceptions related to the innovation and keenly looks for information concerning innovation so that it can be assessed. If the individual (teacher in this case) is not convinced, they would embrace the innovation; if not persuaded, they would refuse to embrace the innovation. When the individuals are persuaded and accept the innovation, it leads to the decision phase which is followed by the implementation (Rogers, 1995). This stage needs full action where the individual mainly changes because of the innovation, albeit a certain degree of indecision about the innovation may still remain. The last phase is confirmation and the individual engages in the re-invention. Rogers (1995) indicated that innovation is the process of discovering a certain teaching method (through training or guideline provided), adopting it (embracing the idea) and implementing it in the classrooms. However, the three first stages; knowledge, persuasion and decisions are central to the adoption of various innovative instructional strategies. They are all based on the views that teachers of English may have towards the adoption and use of various innovative instructional strategies in enhancing the performance of students in English subjects. Every teacher, in this investigation may speak about his/her awareness-knowledge that comes when using innovative instructional approaches (Rogers $\&$ Wallace, 2011). Furthermore, the way the student perceives the innovative instructional approaches will depend on their level of knowledge, persuasion and decision. 


\section{LITERATURE REVIEW}

According to Barrado (2016), innovative strategies are instructional approaches that include those; strategies in which multimedia plays a central role. To their view, Naga and Lyappan (2018) noted that any teaching method that does not destroy teaching outcomes: could be considered as an innovative strategy. The innovative strategy applies to text, images, audio-visuals and animation to provide information. Hence, the process of multimedia learning is more interactive and students' engagement is higher. Advance pedagogy is a way of promoting teaching and learning performance (Naga \& Lyappan, 2018). Eady and Lockyer (2013) informed that there was a tremendous change in technology over the recent past.

The emerging variety and accessibility of technology have opened the working environment and opportunities teachers have to use. Baker et al. (2015) concluded that greater student engagement in English courses is an opportunity for improvement. Various research studies have been conducted across the globe to determine how technology integration influence students' performance in English subject among others in different parts of the world as explained below. Baker et al. (2015) found out that if students are more engaged in learning English in general, their proficiency in English will greatly improve. Another opportunity they found was to leverage the technologies that are aimed at improving English language skills through user involvement. Technologies that invite the user to interact make the learning process more active and successful.

One of the innovative strategies is cooperative learning. According to Aziz and Hossain (2010), it is an instructional method that assists students to learn together in groups to maximise their learning with great motivation and interest. Ramos and Pavon (2015) indicated that it is a teaching strategy in which learners from diverse backgrounds are combined in groups to complete a common assignment. On their part, Dyson and Casey (2012) indicated that it is an instructional strategy in which small groups, each with students of various capacities, utilise various educational tasks to improve their understanding of concepts.
Cooperative learning (CL) has a strong theoretical base. The approach is grounded on motivational, social cohesion, constructivist and social constructivist perspectives. Based on the social constructivist view of learning, learners learn well when they are efficiently engaged in the instructional process and working in a team effort with various students to attain a common objective. Whereas constructivism focuses on individual experiences for understanding new concepts and skills, CL uses not just the learner's own specific experience to understand the concept but also utilises the experience of others. Leaning appears significant when the teacher promotes communication and interaction in the classroom for advancement and development of new knowledge grounded existing or previous knowledge; and students exchange knowledge with other students rather than the presentation of information and being asked by the teacher to read a passage from a book (Sharan, 2015).

The cooperative learning strategy is studentcentred. The method has been implemented widely and successfully in the teaching of English subject. Cooperative learning has become one of the main strategies in language teaching (Lv, 2014). In China, Lv used secondary data to assemble outcomes supporting the use of cooperative learning in English subjects. Lv discovered that cooperative learning methods had a significant impact on teaching and learning English through factual examples in colleges in China. Agashe (2005) indicates that CL use in education would result in sustainable future development. Endeshaw (2015) mentions that CL is an instructional approach where students of different levels of academic achievement work in teams to attain a common objective. This strategy has an interactive form of learning which permits students to take a more active role in the instruction process, undertake responsibility for their tasks, be highly efficient and advance cognitive skills and provide the learner with enjoyment (Waiganjo et al., 2014). In the CL approach, learners are organised in small groups of between $3-5$ members. Each group member, from those considered faster and slower, has an input to make (Slavin, 2010). Rather than setting the learners against one another in a contest for grades and attention, teachers can choose an appropriate CL activity that can efficiently supplement more 
traditional teaching approaches and meet their learners' needs (Mannin \& Lucking, 1996). Using CL strategy as a learning method, the students assist each other and are likely to gain better mastery of content compared to the ones instructed using conventional approaches. Various research studies have been done to examine how CL is used in English classrooms.

Another innovative teaching strategy is the inquiry learning approach. Alameddine and Ahwalb (2016) said that inquiry learning has transpired as an approach that permits smoother and more effective communication. According to them, instruction of English via inquiry approach is becoming popular in second language teaching as it enhances students' capacity to acquire the second language (L2). Another innovative instructional strategy is brainstorming. Rowan (2012) defined brainstorming as an individual or group creativity approach in which efforts are made to ascertain a certain deduction for a specific problem through acquiring information in form of a list of ideas that are suddenly provided by members. The brainstorming idea was made in the year 1953 by Alex Osborn. Osborn argued that individuals working on their own to come up with information are less effective compared to when the ideas come through brainstorming (Al-Maghrawy, 2012). He suggested that ideas needed to be developed without inhibition. Despite this argument could be questionable in currently, UNC (2014) indicates that it is used to imply to all group ideation meetings. Brainstorming is effective and simple when utilised as an approach for teaching social science subjects when introducing new concepts. It is efficient since it triggers learner's background knowledge and acquires their interest (UNC, 2014). When students are learning, the instructor can choose whether they have the adequate background knowledge to proceed with the lesson or not (AlShammari, 2015).

Brainstorming is a recent conference with precise scenery so that to develop a catalogue of ideas which can be utilised as hints to direct learners to the growth of the problem while providing every learner the chance to share his/her ideas and share those ideas with others while also supporting new ideas (Al-blwi, 2006). Al-Maghrawy (2012) indicates that brainstorming technique pre-writing and oral exercises for assisting the student and for expressing ideas by the instructor. It is a method that is utilised under the discussion approach. Brainstorming techniques have a significant role in teaching and learning since they assist students to solve problems, it helps students to benefit from other students' ideas where they develop and build upon them. Further, it assists to build cohesion and relationship among students in classrooms (Sayed, 2009). Brainstorming is an approach used in second language instruction (Manouchehry et al., 2014). They indicated that the brainstorming approach combines a relaxed informal technique to solving a problem and creative judgement. Students are requested to look for thoughts and ideas which at the beginning may look a bit immaterial. It is a great approach that results in the creation of new ideas and motivates learners to carry out writing exercises. The reason is to utilise some of these ideas to develop initial, creative answers to problems. It is argued that ideas that may seem useless may be made useful when the brainstorming approach is factored in. The aim of brainstorming is to guide students to new means of thinking and break from their normal way of thinking. Brainstorming can exist in two ways; a group or individual level. One student may go on brainstorming alone. Before reading a text, the individual acquires its title, attempts to write down on a paper all his/her earlier acquired knowledge about the next topic. The individual may decide to share those ideas with others who are reading the same text. This means at this stage it becomes interactive since there is sharing of the activity in a group. In group brainstorming, there must be a leader who directs and organises the process. In class, the teacher performs the role of a leader. Various researches have examined how brainstorming has been used in English subject instruction.

\section{MATERIALS AND METHODS}

The study was conducted in Turkana Central SubCounty, Turkana County, Kenya. It is one of the six sub-counties; Turkana North, Turkana West, Loima, Turkana East and Turkana South forming the large county (in terms of landmass) in Kenya. This study used a mixed research study involving the use of quantitative and qualitative approaches. According to Creswell (2013), mixed research 
methodology involves the collection of quantitative and qualitative data concurrently to answer research questions. The target respondents for the research involved 10 Heads of Department of Languages, 35 English subject teachers and 486 Form Three students. Considering the number of HODs (Languages) and Teachers of English is small (manageable), all of them participated in the study and were selected through the census method. However, the number of Form III students was high; therefore, a sample was chosen to represent the whole population. The researcher used $30 \%$ of the target Form III students to act as the sample size for the study. The $30 \%$ of the 486 students is 146 . These form III students were selected through a stratified sampling method.

The data collection instruments used in the study included carrying out surveys which involved collecting data through questionnaires and interview schedules. The data analysis process involved the use of quantitative and qualitative strategies as guided by study research design. At first, quantitative analysis of data was done from the two instruments (Form III students and teachers of English questionnaire) separately. Because questions in the instruments were closed-ended, coding and entry were done with the help of SPSS computer software. Analysis of entered data (from two SPSS files) was done through the use of descriptive (percentages, frequencies, means and standard deviation, cross-tabulations) and inferential (Karl Pearson correlation) statistics.

\section{RESULTS AND DISCUSSIONS}

The objective of this study was to establish the innovative strategies that were used in the teaching the English subject in public secondary schools in Turkana Central Sub-County. To answer the question, the researcher collected information from interviews with HODs of languages and questionnaires that were administered to Form III students and teachers of English. At first, the HODs of languages were asked to state how they expected English subject to be taught in schools. HOD No. 5 indicated that:

Can be taught through use of dictation, essay method, storytelling approaches, group work, dialogues, and discussion and explanations strategies.

According to the HOD, these were the main strategies that were used by teachers of English in their school. Another HOD No. 1 said this:

There are critical skills that need to be sharpened for teaching of English to be effective which are; (a) listening skills, (b) speaking skills, (c) reading and comprehension skills, $(d)$ writing skills and (e) critical analysis skills. Hence, English language requires practice on the part of the learner. There should also be a well thought approach on the characteristics of learners to be taught.

HOD No. 1 indicates that the four skills of English are significant and teachers should first understand their learners to know the best approach that they can use to ensure retention of content amongst them. The same views were also shared by HOD No. 2 who said that English subject is supposed to be taught through the use of different approaches depending on the time and age of the learners. Further, the HODs insisted that in secondary school's English subject in secondary schools is divided into four areas to which learners are supposed to gain knowledge, develop skills and competencies associated with them. Further, HOD No. 3 said the following in relation to the approach that (his/her) teachers of English subject used:

A learner centred approach with guidance of the HOD to ensure all approaches have been used in the classroom.

This means that there is a shift in classroom instruction by teachers of English from learner to teacher-centred ones.

Moreover, through the questionnaire given to teachers of English and Form III students, the researcher developed ten innovative strategies from which teachers and students were asked to indicate their usage in a Likert scale of five; Never (1.01.44), Rarely (1.45-2.44), Sometimes (2.45-3.44), Often (3.45 - 4.44) and Always (4.45-5.0). The results of the analysis are given in Table 1 for both students' and teachers' responses computed through means and standard deviation. 
East African Journal of Education Studies, Volume 3, Issue 1, 2021

Article DOI: https://doi.org/10.37284/eajes.3.1.363

Table 1: Usage of Innovative Instructional in Teaching and Learning of English

\begin{tabular}{lllll}
\hline Innovative instructional approach & \multicolumn{2}{c}{ Teachers' Perceptions } & \multicolumn{2}{l}{ Students' perceptions } \\
& Mean & Std. Dev. & Mean & Std. Dev. \\
\hline Communicative language teaching & 3.6364 & 1.19421 & 3.8676 & 1.24012 \\
Constructivist language teaching & 3.8485 & .97215 & 3.5515 & 1.22819 \\
Reflective / Inquiry language teaching & 3.6667 & 1.16369 & 3.1397 & 1.47157 \\
Technology integration language teaching & 2.6061 & 1.02894 & 2.5368 & 1.42936 \\
Cooperative/collaborative language teaching & 3.6970 & .91804 & 3.5662 & 1.30924 \\
Brainstorming language teaching & 3.4545 & 1.12057 & 2.9412 & 1.37040 \\
Project-based language teaching & 2.5758 & 1.14647 & 2.4338 & 1.35374 \\
Task-based language teaching & 3.2424 & 1.03169 & 2.7941 & 1.21788 \\
Problem-based language teaching & 3.2424 & 1.19975 & 2.9706 & 1.29352 \\
Participatory language teaching & 3.8485 & 1.06423 & 3.5809 & 1.17098 \\
\hline Average means & $\mathbf{3 . 3 8 1 8}$ & $\mathbf{1 . 0 8 4 0}$ & $\mathbf{3 . 1 3 8 2}$ & $\mathbf{1 . 3 0 8 5}$ \\
\hline
\end{tabular}

The result in Table 1 with regard to the degree to which various innovative instructional teaching approaches were used in teaching and learning activities in public secondary schools in Turkana Central Sub-County, Kenya. Results show that both students $(M=3.86)$ and their teachers $(M=3.63)$ agreed that communicative language teaching was often used during English language learning in their schools. This means that the communicative language approach was favoured and used by a majority of public secondary school teachers in the teaching of English subjects.

Secondly, the result indicates that both teachers $(M$ $=3.84)$ and students agreed $(M=3.55)$ that constructivist language teaching was often applied during English subject lessons in public secondary schools in the sub-county. This approach involves active learning that permits learners to construct their own knowledge and make sense out of it rather than being directed by teachers on what to do or think about hence facilitating the acquisition of necessary skills by learners. Findings showed differences in the use of inquiry language teaching from teachers' and students' data. Teachers of English reported that they often used $(M=3.66)$ but the Form III students indicated that this method was sometimes $(M=3.13)$ used by their teachers in schools. The result, therefore, shows that this method is used on a moderate level and is used to assist reduce burnout since teachers go beyond their instructional capacity. On the usage of inquiry approach by teachers in public secondary schools in Turkana Central Sub-County, HODs of languages provided different accounts of how it was implemented by teachers of English in their schools. According to HOD No. 4:

Learners are free to inquire from any person or source and later bring the findings together and arrive to a conclusion.

HOD No. 2 said that:

Inquiry based learning is one of the most powerful teaching strategies in the classroom because research tells us that students learn best when they construct their own meaning. Inquiry based learning triggers student curiosity. Teacher act as facilitators during the inquirybased learning process. Here, students are allowed to research a topic and then present their findings and it helps or allows students to learn deeper and wider than before.

This means that in some schools, the inquiry-based approach has been taken seriously as an innovative strategy of raising student performance in the subject. Through using this approach, HOD No. 3 said that:

Enables them find out the weakness of the learners and make them plan adequately.

To HOD No. 1, the inquiry approach was not well implemented in their schools and this suggests that the teachers of English were using other approaches.

The teachers $(M=2.6)$ and students $(M=2.53)$ agreed that technology in language teaching was sometimes used. This could be due to a lack of

191 This work is licensed under a Creative Commons Attribution 4.0 International License. 
necessary infrastructure to support technology integration like ICT facilities, electricity, internet connection and teacher incapacity. This means that the majority of teachers of English in Turkana Central Sub-County resort to conventional teaching approaches in their day-to-day learning in the classroom. Despite the statistics HOD No. 3 indicated that their teachers of English at times used ICT integrative approaches in teaching the subjects as noted below:

They are able to integrate ICT in their content delivery. They are also creative in the way they use the locally available materials to come up with teaching aids.

This means that some teachers go the extra mile of improvising instructional learning materials in order to ensure their lesson objectives are attained in the situation of inadequate material supply. When asked to indicate how technology was integrated into their classroom teaching, HOD No. 2 had this to say:

They are able to source for teaching and learning materials from the internet which they come and use them in English subject learning instruction.

HOD No. 1 indicated that they had not yet started integrating technology:

We are still using the old strategies of teaching and learning English subject in class.

This means that some schools have not yet embraced technological approaches in their English subject instruction process. The research results are different from Harvil et al. (2018) research conducted in Georgia where teachers were found to use technology for daily instructional sessions for English language instruction.

Further, the respondents; teachers $(M=3.69)$ and students $(M=3.56)$ also agreed that collaborative language teaching had been embraced in English subject learning in their schools. This approach ensures that learners are paired in groups by their teachers to ensure maximum use of cooperative activities. It is one of the preferred learner centred approaches in the teaching of language activities in the classroom. With regard to the use of cooperative learning approach, one HOD No. 2 indicated that:
This technique of learning is not well explored in our school.

This shows that some schools have not yet embraced the cooperative/collaborative approach in teaching and learning English subject. HOD No. 1 also said that:

They have cooperative group work as a way of building retention ability amongst the learners.

HOD No. 5 also exemplified the cooperative learning approach by indicating that:
A learner to accept others answers in a discussion. They can do a project differently but later share their findings and deduce their conclusions cooperatively.

In addition, HOD No. 4 also reported that:

In this method, a group of students are grouped together by their teachers to discuss the formation of adjectives and explain it to others.

From the responses made by HODs, most of them agreed that this approach was largely used by teachers of English in their classrooms. The same was recorded by

On the use of brainstorming language approach, teachers indicated to be often $(M=3.45)$ whereas learners indicated this approach is used at times by their teachers in the classroom $(M=2.94)$. Considering English subject is divided into three areas (Paper 1-Functional Skills, Paper 2Comprehension, Literary Appreciation and Grammar and Paper 3-Imaginative Composition and Essay Based on Set Textbooks) in the Kenyan secondary curriculum, teachers can form small groups in the class from which s/he would assign a particular group to focus on a specific topic by themselves that would result in flow of ideas. This happens whereby, to each group, the teacher would pose a question from which students in small groups will be expected to provide possible answers. This application of this approach was found to be low in secondary schools in Turkana Central Sub-County. On the usage of brainstorming, the research found from HODs of languages that it was used at various instances by teachers of English in public secondary schools in Turkana central Sub-County. HOD No. 1 
said that this method was not used in their institution. Whereas others indicated that despite it not been used on regular basis, the approach was used by teachers in situations where students were required to brainstorm on a particular topic. For instance, HOD No. 4 indicated that:

Teachers give some questions to learners for them to have a deep insight from which they would be expected to come up with possible answers amongst themselves.

To some HODs, they indicated that this method is used by teachers where they pose questions to their learners on a random basis. HOD No. 2 explained how it happened in their institution in detail:

This is an intense experience that is strongly focused on a single topic/content for a limited period of time. It provides a very different and stimulating student interaction with time. The ideas generated tend to serve as catalysts for new responses. We normally divide the class into small groups of between 5-7 students. We arrange them in separate sections of the classroom making sure they have writing materials. We give them the tasks and allow them to brainstorm.

This suggests that some schools favoured regular use of brainstorming approach where the teacher just provide the item to be brainstormed and leave the rest to students in small groups to come up with a solution.

Results also pointed to differences in project-based language teaching approach usage where teachers said that they at times used $(M=2.57)$ with lower mean values scores but students indicated that this approach was rarely used $(M=2.43)$ in classroom instruction in public secondary schools in the study area. This means that teachers do not favour the use of this approach despite its significance in engaging students with transformative and dynamic learning experiences which are beyond the classroom setting. The reason could be due to teacher's inadequate knowledge and skills in teaching English as an integrated subject. Moreover, it is associated with the use of technology to which the research had earlier established to be lowly embraced by teachers in the study area. With regard to task-based instruction, both teachers $(M=3.24)$ and students
$(M=2.79)$ agreed that it was sometimes used in teaching and learning English subject activities in the public secondary in Turkana Central SubCounty. The low usage of this approach could be due to the environmental situation since this approach involves students doing meaningful tasks using the target language and may involve conducting an interview or discussions. Because of the low number of schools and distance from school to urban centres, it is impossible for this approach to be used as students can only interview their fellow teachers and not other professionals like lecturers, doctors, engineers from where they are located. With regard to problem-based language use, results showed similarity in responses from teachers $(M=$ $3.24)$ and students $(M=2.97)$ who indicated that this method is sometimes used during English subject instruction in public secondary schools in the study area.

When asked about participatory language teaching, both teachers $(M=3.84)$ and students $(M=3.58)$ had a common observation that it was often used in teaching English subject in their schools.

Composite data values show that both teachers of English $(M=3.38, S D=1.08)$ and Form III students $(M=3.13, S D=1.17)$ shared a common position that innovative instructional learning approaches were sometimes used in English subject instruction in public secondary schools in Turkana Central Sub-County. Further, the obtained means statistics show higher scores for teachers' responses compared to students. Contrary to the study results, research done in Central Taiwan by Hung and $\mathrm{Li}$ (2017) found out that innovative teaching performance among teachers was favourable. Through the interview, the HODs were asked to indicate how innovative instructional approaches were used by teachers of English in their schools. HOD No. 1 mentioned the following:

Honestly speaking, this is an area that has not been well explored well here. I would love to see us taking the route of innovative teaching moving forward.

The above responses from HOD No. 1 suggest that innovative strategies are not regularly applied in some schools. This finding was corroborated by HOD No. 5. Further, HOD No. 4 reported that: 
It is used in a manner to make students remember and retain content.

HOD No. 3 said that:

They are able to integrate ICT in their content delivery. They are also creative in the way they use locally available materials to come up with teaching aids.

The above responses show that some teachers of English teachers in secondary schools improvise teaching and learning resources to enable them utilise several innovative instructional strategies like; project learning, task-based, and collaborative approaches.

\section{Performance of Learners in English}

The study asked the teachers of English and Form III students to indicate performance in English in the following areas: from group work, exams, CATs, individual assignments among others on a scale of five; Very High (5), High (4), Average (3), Below Average (2) and Poor (1). This was done in accordance with the conceptual framework variables of students' performance in English (Figure 1.1) and the items included in the questionnaire for Form III students (Appendix III, Section E) and Teachers of English (Appendix II, Section E). The results of the analysis are presented in Table 2.

Table 2: Performance of English in Turkana Central Sub-County

\begin{tabular}{|c|c|c|c|c|c|}
\hline \multirow[t]{2}{*}{ No } & \multirow[t]{2}{*}{ Performance Area } & \multicolumn{2}{|c|}{$\begin{array}{l}\text { Perception of Teachers of } \\
\text { English }\end{array}$} & \multicolumn{2}{|c|}{$\begin{array}{l}\text { Perception of Form III } \\
\text { students }\end{array}$} \\
\hline & & $\mathbf{M}$ & SD & $\mathbf{M}$ & SD \\
\hline 1 & KCSE examinations (Paper $1,2 \& 3$ ) & 2.1818 & .98281 & & \\
\hline 2 & End term and end year examinations & 2.6970 & .72822 & 3.1544 & .98039 \\
\hline 3 & Group work exercises & 3.8485 & .83371 & 3.6250 & 1.12175 \\
\hline 4 & Reading skills & 3.1515 & .87039 & 3.2941 & .91180 \\
\hline 5 & Speaking skills & 2.7273 & .91079 & 2.7647 & 1.18156 \\
\hline 6 & Writing skills & 3.1515 & 1.27772 & 4.0368 & .96922 \\
\hline 7 & Pronunciation and vocabulary skills & 2.3939 & 1.24848 & 3.1691 & .97794 \\
\hline 8 & Individual exercises and assignments & 3.0606 & .70442 & 3.3897 & .91224 \\
\hline \multirow[t]{2}{*}{9} & English CATs & & & 3.1765 & .98042 \\
\hline & Average score & 2.9015 & 0.9446 & 3.3263 & 1.0044 \\
\hline
\end{tabular}

Key: M-Mean, SD-Standard Deviation

The result in Table 2 on KCSE performance in English Paper 1 to 3 shows that teachers indicated that the performance of their students was below average with a mean value of 2.1 and a standard deviation score of 0.98 . This means that poor performance in English subject in KCSE examinations is a challenge being faced by a majority of public secondary schools and concurs with secondary data collected from Sub-County Director of Education Office. With regard to performance in end-term examinations, both teachers and students indicated that it was average but teacher mean value was less $(M=2.69)$ compared to Form III students $(M=3.15)$. This means that teachers perceive students' performance in English end-of-year examinations to be slightly average. With regard to group work exercises, both teachers of English $(M=3.84)$ and Form III students $(M=3.62)$ agreed that performance in such activities which are done by students in the group was high.

Research findings also showed that both teachers $(M=3.15)$ and students $(M=3.29)$ rated English reading skills as average. This means that majority of students in secondary schools in Turkana Central's reading skills are on a moderate level. On speaking competency level, both students $(M=$ 2.76) and teachers of English subject $(M=2.82)$ agreed that it was on a moderate level. This means that majority of secondary school students in Turkana Central Sub-County level of speaking English is at a moderate level. Scores on students writing skills revealed differences where teachers of English rated them as average $(M=3.15)$ but Form III students themselves rated their writing skills as

194 | This work is licensed under a Creative Commons Attribution 4.0 International License. 
high (4.03). This means that teachers and students differ on the competency in writing English words well as part of competencies associated with the subject. On students' level of mastery of vocabulary and pronunciation skills, teachers indicated that it was low $(M=2.39)$ whereas Form III students rated their level of performance in the areas as moderate $(M=3.16)$. This means that a significant number of Form III students' pronunciation and vocabulary skills are still below average as perceived by teachers of English in the sub-county. On the performance in individual assignments and exercises, both teachers of English $(M=3.06)$ and Form III students $(M=3.38)$ agreed that students' performance in their individual assignments and exercises was on average. When students were asked to rate their performance in continuous indicated that it was on average $(M=3.17)$. Average statistics indicate the difference in performance in English rating for Form III students which were higher $(M=3.32, S D=1.0)$ compared to teachers of English $(M=2.90, S D=0.94)$. However, they both agreed that the performance of students in English was average and therefore this study investigates the extent to which the performance trend has been affected by the usage of innovative instructional approaches in the subject.

To examine the effect of innovative instructional approaches (Table 1) towards academic performance in English (Table 2), a Karl Pearson correlation was computed between the two kinds of respondents. The results are summarized in Table 3.

Table 3: Correlations on Innovative Instructional Approaches and Students Performance in English

\begin{tabular}{lllll}
\hline & & $\begin{array}{l}\text { Innovative } \\
\text { Approaches }\end{array}$ & $\begin{array}{l}\text { Instructional } \\
\text { Performance } \\
\text { English }\end{array}$ & in \\
\hline Innovative & Instructional & Pearson Correlation & 1 & $.566^{*}$ \\
Approaches & Sig. (2-tailed) & & .001 \\
& N (Teachers) & 33 & 33 \\
\hline Performance in English & Pearson Correlation & $.320^{*}$ & 1 \\
& Sig. (2-tailed) & .000 & \\
& N (Form III students) & 136 & 136 \\
\hline
\end{tabular}

**. Correlation is significant at the 0.05 level (2-tailed).

The results show that from both respondents, at $95.0 \%$ confidence level, the use of innovative teaching approaches would result in improvement in English subject performance in secondary schools. However, the correlation values for teachers of English were above average $(r=0.566)$ compared to Form III students $(r=0.320)$ suggesting that teachers perceive that the innovative instructional approaches are contributing to above-average performance of students in the subjects. For the students, they indicated that their teachers of English did not regularly use the approaches and therefore have a minimal positive effect on their academics. Nevertheless, the two correlation values suggest that continuous and regular usage of innovative instructional approaches would boost the performance of students in English in secondary schools in Turkana Central Sub-County, Kenya.

The teachers of English were asked (through openended questions) to indicate the reasons for their non-utilisation of innovative strategies of teaching English in their schools. Their feedback was coded into quantitative form (given numerical values) and is presented in Table 4.

Table 4: Reasons for Teacher Non-Utilisation of Innovative Instructional Approaches

\begin{tabular}{lll}
\hline Reasons & Frequency & Percent \\
\hline Lack of training & 4 & 12.1 \\
Inadequate capacity & 1 & 3.0 \\
Would result in non-syllabus coverage & 2 & 6.1 \\
Inadequate resources & 7 & 21.2
\end{tabular}

195 | This work is licensed under a Creative Commons Attribution 4.0 International License. 


\begin{tabular}{lll}
\hline Reasons & Frequency & Percent \\
\hline Huge workload which hinders preparation & 2 & 6.1 \\
Constant power interruption & 17 & 51.5 \\
Total & 33 & 100.0 \\
\hline
\end{tabular}

Results show that 4 (12.1\%) of teachers of English reported that lack of training hinders their application of the innovative approaches; 7 (21.2\%) mentioned that inadequate resources inhibit them; 2 $(6.1 \%)$ reported that the usage of the approaches would lead to syllabus non-completion $(3.0 \%)$ indicated that they did not have the adequate capacity to use the approaches in teaching and learning of English subject in the classroom. More than half $17(51.5 \%)$ reported that constant power interruption affected their utilisation of innovative instructional approaches because they were dependent on power (ICT devices mainly).

\section{CONCLUSIONS AND RECOMMENDATIONS}

Research results showed that both HODs of languages, teachers of English and Form III students agreed that innovative instructional strategies were moderately used in classroom instruction in public secondary schools in Turkana Central Sub-County. According to teachers of English, the three common and regular applied teaching strategies consisted of; constructivist language teaching $(M=3.84)$, participatory language teaching $(M=3.84)$ and cooperative language teaching $(M=3.69)$. For Form III students, the three main innovative instructional teaching strategies used by their teachers of English were; communicative language teaching $(M=3.86)$, participatory language teaching $(M=3.58)$ and cooperative language teaching $(M=3.56)$. This outcome suggests that participatory and cooperative (collaborative) innovative teaching approaches were the main approaches used by teachers of English in the study area. The three strategies that teachers ranked to be lowly used were; problem-based learning ( $M=$ $3.24)$, technology integration $(M=2.6)$ and projectbased learning $(M=2.57)$.

For Form III students, they indicated that the following innovative approaches were lowly used; task-based teaching $(M=2.79)$, technology integration teaching $(M=2.53)$ and project-based language teaching $(M=2.43)$. From these outcomes, it can be seen that technology integration and project-based language teaching was rarely used during English subject lessons in public secondary schools in Turkana Central Sub-County. In general, the research found out that usage of innovative instructional approaches had a significant positive relationship based on chi-square statistics $(p<0.05)$ on the performance of students in English subjects. In recommendations, there is a need for the Ministry of Education through KICD to provide detailed and appropriate guidance on the usage of diverse innovative instructional teaching approaches to teachers and There is a need for the government to ensure that necessary resources are availed together with appropriate infrastructure is provided in schools to ensure full utilisation of various innovative strategies that require internet and electricity supply.

\section{REFERENCES}

Agashe, L. (2005). Sustainable Development and Cooperative Learning in the Formal Education System in India. Retrieved online from https://citeseerx.ist.psu.edu

Alameddine, M. M., \& Ahwal, H. W. (2016). Inquiry based teaching in literature classrooms. Procedia-Social and Behavioural Sciences, 232, 332-337.

Al-bwli, Q. (2006). The effectiveness of using brainstorming strategy in developing creative thinking in Islamic Education among Third secondary students in Tabouk City. Master Thesis. Mut'a University, Krak. Jordan.

Al-maghawry, A. (2012). Effectiveness of Using the Brainstorming Technique to Learn Some Basic Skills and Collection of Knowledge for Beginners in Volleyball. World Journal of Sport Sciences, 6 (4), 361-366.

Al-Shammari, M. K. (2015). Effective brainstorming in teaching social studies for elementary school. American International Journal of Contemporary Research, 5(2), 60-65.

196 | This work is licensed under a Creative Commons Attribution 4.0 International License. 
Anburaj, M. G., Christopher, G., \& Ming, N. (2014). Innovative methods of teaching English language. IOSR Journal of Humanities and Social Science, 19(8), 62-65.

Aziz, Z., \& Hossain, M. A. (2010). A comparison of cooperative learning and conventional teaching on students' achievement in secondary mathematics. Procedia-Social and Behavioural Sciences, 9, 53-62.

Baker, R., Minh, D. D. \& Mailand, S. (2015). The Use of Technology to Enhance English Language (ESL) Teaching. An Interactive Qualifying Project Report Submitted to the Faculty of Worcester Polytechnic Institute.

Barrado, J. N. (2016). Innovative Strategies to improve the Learning. Unpublished Master's Thesis. Norwegian University of Science and Technology.

Creswell, J. W. (2013). Designing and Conducting Mixed Method Research (2nd ed.). Thousands Oaks, CA: SAGE.

Dyson, B., \& Casey, A. (2012). Cooperative Learning in Physical Education: A Researchbased Approach. Routledge.

Eady, M. J., \& Lockyer, L. (2013). Tools for learning: technology and teaching strategies. $\mathrm{L}$ earning to teach in the primary school, Queensland University of Technology, 71.

Endeshaw, A. D. (2015). The effect of cooperative learning on students' EFL reading comprehension: Meshentie grade nine high school students in focus. Education Journal, 4(5), 222-231.

Ganyaupfu, E. M. (2013). Teaching methods and students' academic performance. International Journal of Humanities and Social Science Invention, 2(9), 29-35.

Harvil, H.R. (2018). Teacher Perceptions on the Use of Technology with English Language Learners. Unpublished Doctor of Education Dissertation, Liberty University.

Hightower, A. M., Delgado, R., Lloyd, S., Wittenstein, R. Sellers, K., \& Swanson, C.
(2011). Improving student learning by supporting quality teaching: Key issues, effective strategies. Bethesda, MD: Editorial Projects in Education.

Hung, \& Li, (2017). Teacher perceptions of professional role and innovative teaching at elementary schools in Taiwan. Educational and Research Reviews, 12(21), 1036-1045. https://doi.org/10.5897/ERR2017.3373

Ismail, A. (2016). The impact of information communication and technology on students' academic performance: Evidence from Indonesian EFL classrooms. International Journal of Indonesian Studies, 1(7), 120-130.

Khan, A.S. (2008). To Evaluate the Effectiveness of Cooperative Learning vs. Traditional Learning Method. Unpublished doctoral dissertation. Islamabad University, Pakistan.

Khan, M. S., Hussain, S., Ali, R., Majoka, M. I., \& Ramzan, M. (2011). Effect of inquiry method on achievement of students in chemistry at secondary level. International journal of academic research, 3(1), 955-959.

Lucking, R., \& Manning, M.L. (1996). Instruction for low-achieving young adolescents: Addressing the challenge of a generation imperiled. Preventing School Failure, 40(2), 8287.

Lv, Y. (2014). Cooperative learning: An effective approach to college English learning. Theory and Practice in Language Studies, 4(9), 19481953.

Manouchehry, A., Farangi, M., Fatemi, M., \& Qaviketf, F. (2014). The Effect of Two Brainstorming Strategies on the Improvement of Iranian Intermediate EFL Learners' Writing Skill. International Journal of Language Learning and Applied Linguistics World, 6(4), 176-187.

Mothe, P. S. (2000). Innovative techniques of teaching vocabulary at the intermediate level in the second language classroom.

$197 \mid$ This work is licensed under a Creative Commons Attribution 4.0 International License. 
Naga, P. C. S. \& Iyappan, V. (2018). Innovative strategies of teaching and learning. Journal of Applied and Advanced Research, 3(1) 200-22.

Ongalo, R. A., Wambugu, P. W., \& Anditi, Z. O. (2014). Effects of Computer-Based Cooperative Learning Method on Students' Attitudes towards English Grammar in Secondary Schools in Njoro Sub-County, Kenya. Asian Journal of Social Sciences \& Humanities 3 (2) 30, 36.

Osborn, A. (1953). Applied Imagination: Principles and Procedures of Creative Problem Solving. New York, New York: Charles Scribner's Sons.

Ramos, M. C., \& Pavón, V. (2015). Developing cooperative learning through tasks in Content and Language Integrated Learning. Multidisciplinary Journal of Educational Research, 5(2), 136166.doi:10.17583/remie.2015.1429

Rogers, E. M. (1995). Diffusions of innovations (4th Ed.). NY: Free Press.

Rogers, R. K., \& Wallace, J. D. (2011). Predictors of technology integration in education: A study of anxiety and innovativeness in teacher preparation. Journal of Literacy \& Technology, 12(2), 28-61.

Rowan, K. (2014). Glossary of Instructional Strategies. Beesburg.com. http://www.beesburg.com/edtools/glossary.html

Sayed, A.W.H., (2009). Sources of the effectiveness of a program using the mental strike in the development of skills of linguistic communication in the third preparatory class, the first conference (5-6) March, Assiut University, Faculty of Education, New Valley, p. 292.

Sharan, Y. (2015). Cooperative Learning for Academic and Social Gains: valued pedagogy, problematic practice. European Journal of Education, 45(2), 300 - 313.

Slavin, R. (2010). Co-operative learning: what makes group-work work? In Dumont, H., Istance, D., and Benavides, F. (eds.), The Nature of Learning: Using Research to Inspire Practice. OECD Publishing.
Sockman, B. R. (2015). Innovative teacher's perceptions of their development when creating learner centered classrooms with ubiquitous computing. International Education Research, 3(3), 26-48.

Tebabal, A., \& Kahssay, G. (2011). The effects of student-centered approach in improving students' graphical interpretation skills and conceptual understanding of kinematical motion. Latin-American Journal of Physics Education, 5(2), 9.

Tran, V. D. (2014). The effects of cooperative learning on the academic achievement and knowledge retention. International journal of higher education, 3(2), 131-140.

UNC. (2014). Design and problem solving in technology. Albany, NY: Delmar.

Vitthal, P. C., Subhash, A. R., Sharma, B. R., \& Ramachandran, M. (2015). Emerging trends and future prospects of medical tourism in India. Journal of pharmaceutical sciences and research, 7(5), 248.

Waiganjo, M. M., Wambugu, P. W., Ngesa, F., \& Cheplogoi, S. (2014). Effects of co-operative learning approach on secondary school students' academic achievement in Agriculture in Nakuru sub-County, Kenya. International Journal of Humanities Social Sciences and Education, 1(7), 191-197.

198 | This work is licensed under a Creative Commons Attribution 4.0 International License. 